\title{
SURVEY AND LEVEL OF INFESTATION OF PACHNODA INTERRUPTA (OLIVER) (COLEOPTERA: SCARABAEIDAE) IN GEDARIF STATE
}

\author{
Samaher Emame Mohemed Osman \\ Department of Crop protection
}

University of Khartoum, Shambat, 13314, Khartoum North, Sudan

\author{
Hamid Ahmed Hamid \\ Department of Crop protection \\ University of Khartoum, Shambat, 13314, Khartoum North, Sudan \\ Abd Elaziz Sulieman Ahmed Ishag \\ Department of Crop protection \\ University of Khartoum, Shambat, 13314, Khartoum North, Sudan \\ Mubarak Abdelrahman Salim Eisa \\ Department of Crop protection \\ University of Zalingei, Zalingei, Sudan
}

\begin{abstract}
The study aimed to estimate the level of infestation and percent of infestation caused by the sorghum chafer (Pachnoda interrupta) (Coleoptera: Scarabaeidae) on sorghum and sunflower crops in Gedarif State. The study also investigates the feeding behavior of the beetle. A field survey was conducted in Gedarif State in four localities (University of Gedarif, AL Azaza Sogora, Pasonda, and Algadambalia). In each locality two (sunflower and sorghum) farms were inspected, except at the University of Gedarif, only sunflower was inspected, no sorghum was grown. Observations on the selected farms were made on 60 randomly selected plants (10 footsteps from plant to plant) using cross diagonal method in Gedarif State. Data obtained from the field survey were subjected to descriptive statistics. The level of infestation and percent of infested heads were calculated for data obtained from the field survey. Least Significant Difference (LSD) was used for mean separation. Results indicate that the $\boldsymbol{P}$. interrupta was not found in sunflower and sorghum farms at Pasonda and Algadambalia localities. In sunflower grown at the University of Gedarif a level of infestation of 0.37 and a percent of infestation of $17.7 \%$ were recorded. In a sunflower farm, in Al Azaza Sogora locality a 6.31 level of infestation and a $91.9 \%$ percent of infestation were recorded. In sorghum,
\end{abstract}

however, a level of infestation of 2.19 , and a percent of infestation of $53.2 \%$ were detected.

Keywords - Pachnoda interrupta, Infestation level, Gedarif State, Sudan

\section{INTRODUCTION}

Wild sunflower has long been known in Sudan, and heliotropism of the young flower head has involved the plant in a legend from which it gained its vernacular name "abbadeshams" (worshiper of the sun) [1]. However, the commercially grown cultivars were first introduced into the country for experimental purposes during the 1930s, and various agronomic aspects of the crop have been intermittently studied since then, the drive being mainly a personal interest of investigators. Only in the 1980s has the large scale commercial growing of sunflower attracted attention, and the acreage allocated to it is rapidly increasing. The crop is mainly produced for the extraction of edible oil, although its meal forms a high-protein source and is blended in animal feed. Sunflower is grown as rain fed crop in summer and under irrigation in winter [2]. From planting to seed maturity the sunflower plant harbours a wide range of insect species, including both noxious and beneficial groups. Among the former category the bollworm Helicoverpa armigera stands out as the most important and most destructive pest of 


\section{International Journal of Engineering Applied Sciences and Technology, 2020 \\ Vol. 4, Issue 11, ISSN No. 2455-2143, Pages 73-77 \\ Published Online March 2020 in IJEAST (http://www.ijeast.com)}

sunflower. Also the armyworms Spodoptera exigua and $S$. littoralis are early season leaf feeders, but they rarely attain damaging levels. The blister beetle Epicauta aethiops is also an early season defoliator. The flea beetle Apophylia saliens devastates a whole plantation when large numbers of adults attack the seedlings. However, the most conspicuous species that attack the flower heads are the cetoniids Pachnoda interrupta and Pachnoda marginata. It is the tendency of these beetles to cluster on flower heads that makes them noticeable. They principally feed on anthers but the soft seeds are also consumed and the occupants of flower head usually stay on it until they devour all its contents [1].

Sorghum (Sorghum bicolor L.) is a cultivated tropical cereal grass. It is generally, although not universally, considered to have first been domesticated in North Africa, possibly in the Nile or Ethiopian regions as recently as 1000 BC. Sorghum is an important energy and cereal crop worldwide that is widely cultivated for food, fiber, forage, ethanol, and sugar production [3-5]. Today, sorghum is cultivated across the world in the warmer climatic areas. It is quantitatively the world's fifth most important cereal grain, after wheat, maize, rice and barley. In Africa, sorghum is still largely a subsistence food crop.

World annual sorghum production is over 60 million tons, of which Africa produces about 20 million tons. This makes sorghum, quantitatively the second most important cereal grain in Africa after maize. Sorghum culture started in Ethiopia or Sudan [6]. Sudan is one of the few countries that obtain the bulk of its nourishment from sorghum [7]. Sorghum constitutes about $65 \%$ of the total cereal consumption in the country, it constitutes about $70 \%$ of the calories in the meal and a proportional percentage of protein, the estimated consumption per capita is about $92.1 \mathrm{~kg} /$ year [8].

Sorghum chafer, Pachnoda interrupta (Coleoptera: Scarabaeidae: Cetoniinae) is one of the major insect pests with great notoriety for attacking the crop [9]. It was first reported attacking sunflower on the African subcontinent in Ethiopia in 1992 [10]. During out break the pest can cause 70-100\% yield losses [11-12]. The adult of $P$. interrupta feeds on the flowers and grains during the milky stage of sunflower and serious damage has been reported to occur when 2-3 beetles present/plant [13]. During the early 1990s, the sorghum chafer emerged as a key pest on sorghum in Ethiopia [12].

$P$. interrupta is present in semi-arid parts of Africa which are subject to strong seasonal variations in rainfall and temperature, mainly in the Sahel and Sudan Ecoregions [1417]. In Sudan it is uncommon but widespread in some parts of the central rain lands, for instance in the Nuba Mountains, Gedarif area and Khartoum area [14, 18]. The beetle feeds towards the end of the rainy season on the milky-ripe grains of sorghum, and millet heads, but flowers of sunflower, henna, cucumber, roses and capsules of okra are also attacked [14].

During autumn of 2011 an outbreak of Pachnoda interrupta occurred for the first time in Sudan on four genotypes of sorghum (Sorghum bicolor), four of pearl millet (Pennisetum glaucum) and eight of sunflower (Helianthus annuus) in the Gezira Research Station farm [19].

Due to the importance of sunflower and sorghum as commercial and food crops and the high damage caused by sorghum chafer on these crops this study aims to answer the following questions:

* What is the level of infestation of sorghum and sunflower caused by the sorghum chafer in Gedarif State?

* What is the percentage of infestation of sorghum chafer in sorghum and sunflower in Gedarif State?

* What is the sorghum chafer feeding behavior?

\section{MATERIALS AND METHODS}

\section{A. Field Survey}

A field survey was conducted in Gedarif State in four localities; University of Gedarif, AL Azaza Sogora, Pasonda and Algadambalia to determine the percent of infested plants and the level of infestation by the sorghum chafer. In Algadambalia the survey was conducted in sunflower farm of 500 feddans and a sorghum farm of 900 feddans. In Pasonda locality the survey was conducted in sorghum farm of 1700 feddans and a sunflower farm of 250 feddans. Observations on the selected sunflower and sorghum farms were made on 60 randomly selected plants (10 footsteps from plant to plant) during the period September-October 2016 using cross diagonal method in Gedarif State. The percentage of infested plants was calculated using the flowing formula:

Percent infested plants $=$

$\frac{\text { Number of infested plants }}{\text { total number of tested plants }} \times 100$

The level of infestation was expressed as the mean number of insects/head or disc over the total number of inspected heads or discs.

\section{B. Feeding Behavior}

The feeding behavior of $P$. interrupta was observed on the surveyed plot by carefully examining the disc of sunflower and the head of sorghum.

\section{Statistical Analysis}

The collected data from the survey were subjected to descriptive statistics, as described by Gomez and Gomez (1984) using SAS software version 9.2. 


\section{International Journal of Engineering Applied Sciences and Technology, 2020 \\ Vol. 4, Issue 11, ISSN No. 2455-2143, Pages 73-77 \\ Published Online March 2020 in IJEAST (http://www.ijeast.com)}

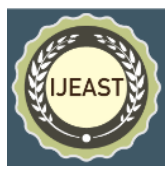

\section{RESULTS}

\section{Field Survey of $P$. interrupta}

\section{University of Gedarif and Al Azaza Sogora Localities}

The survey that was carried out in a 10-feddans sunflower farm of the University of Gedarif revealed that the level of infestation was 0.37 (Fig. 1) and the percent of infested plants was $17.7 \%$ (Table 1). In Al Azaza Sogora locality in a 50feddans farm of sunflower, the level of infestation was 6.31 (Fig. 1) and the percent of infested plants was $91.9 \%$ (Table 1). In a 10-feddans farm of sorghum, the level of infestation was 2.19 and the percent of infested plants was $53.2 \%$ (Fig. 1 \& Table 1).

Table 1: Percent of sorghum and sunflower plants infested with Pachnoda interrupta in four localities of Gedarif State

\begin{tabular}{lcc}
\hline \multicolumn{1}{c}{ Locality } & Sunflower & Sorghum \\
\hline University of Gedarif & $17.7 \%$ & - \\
Al Azaza Sogora & $91.9 \%$ & $53.2 \%$ \\
Algadambalia & $0 \%$ & $0 \%$ \\
Pasonda & $0 \%$ & $0 \%$ \\
\hline
\end{tabular}

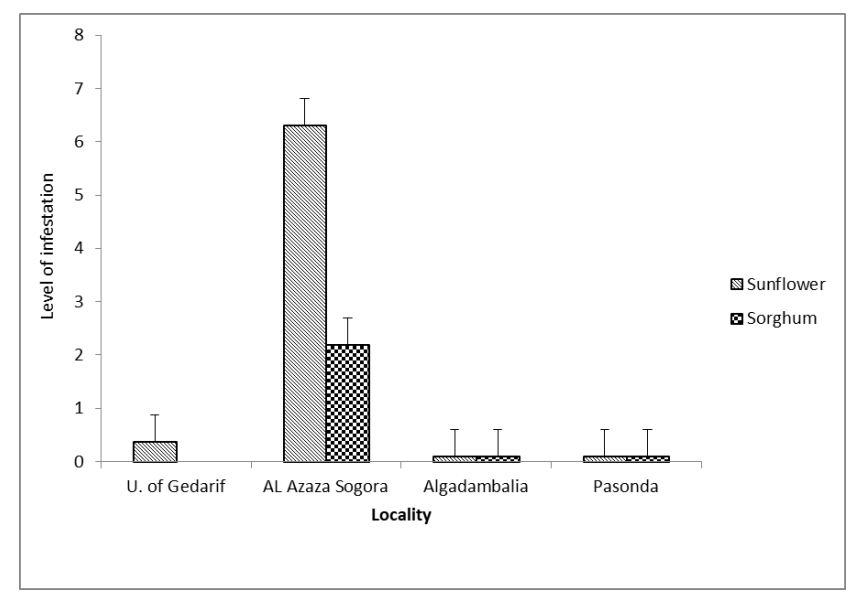

Fig. 1. Mean level of infestation on sorghum and sunflower in four localities of Gedarif State

\section{Algadambalia and Pasonda Localities}

The survey revealed that the sorghum chafer was not detected in either sunflower or sorghum farms in the two localities. Accordingly, the level of infestation and the percent of infested plants were found zero for both crops in the two localities (Fig. $1 \&$ Table 1).

\section{Assessment of the Infestation Level}

The mean level of infestation on sunflower in the four localities in Gedarif State was found 1.67 and that on sorghum was found 0.55 in the same localities. Furthermore, the level of infestation varied with the locality, it was the highest at $\mathrm{AL}$ Azaza Sogora (4.25) as compared to that of the other localities. At Al Azaza Sogora locality the infestation level on sunflower (6.31) was three times that on sorghum (2.19).

\section{The beetle feeding behavior}

The results showed that the adult beetle is the damaging stage it was found feeding on the flowers and suck out all the contents of sorghum (Figure 2A). Further, the beetle feed on the soft peduncle of sorghum in late sown sorghum fields. They are observed to aggregate on sorghum heads sucking out all the contents of the grain at the early milk stage. On the other hand, the beetle feeding behavior of Pachnoda interrupta on sunflower started on the periphery of the disc toward the center (Figure 2B).
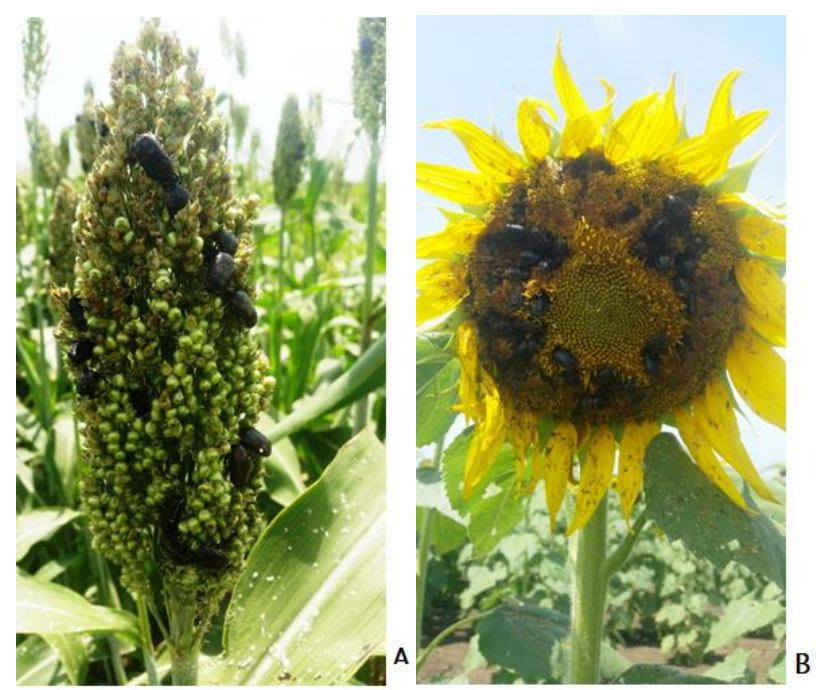

Figure 2: Adult of Pachnoda interrupta feeding on sorghum head (A) and sunflower disc (B)

\section{DISCUSSION}

Insect pests play a major role and responsible for quality and quantity deterioration. Among the insect pests, the sorghum chafer Pachnoda interrupta attacks sunflower and sorghum at the milky stage in the main producing area (Gedarif State). The Pachnoda interrupta was recorded in Gedarif State at AL Azaza Sogora locality on sunflower and sorghum, and at the University of Gedarif on sunflower on one hand. On the other hand, the Pachnoda interrupta was not encountered at Algadambalia and Pasonda localities on the two crops. This could be due to the fact that sorghum in these localities did not reach the milky stage. For sunflower the reason may be variety of the seeds or sowing date.

In this study, the highest level of infestation, recorded at AL Azaza Sogora, was 6.31 in sunflower and 2.19 in sorghum, but low level of infestation (0.37) was recorded at the University of Gedarif in sunflower farm. The result obtained at AL Azaza Sogora locality could be attributed to the fact that the farm is 


\section{International Journal of Engineering Applied Sciences and Technology, 2020 \\ Vol. 4, Issue 11, ISSN No. 2455-2143, Pages 73-77 \\ Published Online March 2020 in IJEAST (http://www.ijeast.com)}

located near a forest where animal herders use for their animal grazing. This creates an optimum situation for mating and egg laying by the beetles, i.e. they lay their eggs in the animal dung where the larvae feed [18]. The farm where the investigation was carried out is approximately 30 meters from the forest. Therefore, the emerging adult beetles can easily find and attack the crop. In this inspected farm, sorghum and sunflower crops were grown close to each other, approximately 10 meters apart. The mean of infestation level on sunflower was (1.67) it was three times that on sorghum (0.55) this indicates that the pest has more preference for sunflower to sorghum.

Concerning the feeding behavior of the sorghum chafer on sunflower, the beetle started feeding on the periphery of the disc toward the center. In this manner the beetle follows the development of the seeds in the disc; those at the periphery develop earlier compared to those at the center of the disc. On sorghum heads, the beetles partially or completely consume the grain endosperm. At the level of spike/panicle, the beetles feed from the top and proceed downward. The infested part of either crop turned chafed; this observation is in line with that of Tag Elsir et al. [19].

\section{CONCLUSION}

- Infestations of sunflower and sorghum plants with sorghum chafer (Pachnoda interrupta) always synchronized with the milky stage and severe infestation results in empty disc of sunflower or panicle of sorghum.

- The mean level of infestation in sunflower was (1.67) it was three times that in sorghum (0.55).

- The level of infestation varied with locality, it was higher at Al Azaza Sogora (4.25) as compared to the other localities in Gedarif State.

- The feeding behavior of Pachnoda interrupta on sunflower started on the periphery of the disc toward the center. While on sorghum heads it feeds on the top and proceed downward.

\section{REFERENCE}

[1] A.A. Musa, M.E. Eltigani, "Insect Pests of Sunflower in the Sudan".14th international. Sunflower Conference, Entomology and Weeds, Beijing/Shenyang, China, June 12-20, 1996 Vol. 1. 511-517.

[2] H.M. Ishag, "Sunflower": a potential new crop for Sudan. In: Omran, A. (editor): Oil crops, Sunflower Linseed and Sesame. Proceedings of the forth Oil Crops Network Workshop. Niojro, Kenya, 25-29 January 1988.

[3] G. Li, W. Gu, "Sweet Sorghum". Chinese Agriculture Technology and Sciences Publishing House, Beijing, 2004.

[4] G.S. Liu, Q.Y. Zhou, S.Q. Song, H.C. Jing, W.B. Gu, X.F. Li, M. Su, R. Srinivasan, "Research advances into germplasm resources and molecular biology of the energy plant sweet sorghum". Chin. Bull. Bot. 44, 253- 261, 2009.

[5] C. Guo, C.X.F. Wei, Z. Jianzhou, L. Guihua, "Sorghum Insect Problems and Management". Journal of integrative Plant Biology. 53(3), 178-192, 2010.

[6] J.H. Martin, "History and classification of sorghum". In: Wall, J.S. and Press, W.M. (eds). Sorghum Production (cited by Dirar, H.A., 1993 above), 1970.

[7] H. Dogett, "Sorghum”. Longman Group UK Limited, Burnt Harlow, Essex. Co-published in USA by John Wiley \& Sons, Inc., New York (cited by Dirar, H.A., 1993 above), 1988.

[8] H.A. Dirar, "The Indigenous Fermented Foods of Sudan": A Study in African Food and Nutrition, 576 pp, 1993.

[9] FAO, "Food and Agricultural Organization". Annual Production Year Book, Rome, 1972.

[10] Ethiopian Humanitarian Organization, Univ. of Penn. African Studies Centre Press, pp. 36, 2000.

[11] W-H. Yitbarek, L. Hiwot, "Preliminary yield loss assessment on sorghum due to sorghum chafer, Pachnoda interrupta (Olivier) in Amhara Region". pp 39-43. In: Proceedings of the Workshop on the Development, Monitoring and control strategy against sorghum chafer, Pachnoda interrupta (Olivier), (Coleoptera: Scarabaeidae) in Ethiopia. Addis Ababa, 2000.

[12] B. Habtegebrie, E. Getu, M. Dawd, E. Seyoum, G. Atenafu, Y. Welde-Hawariat, S. Ekesi, Y. Hilbur, M. Larsson, "Field level auto-inoculation of sorghum chafer, Pachnoda interrupta (Olivier) (Coleoptera: Scarabaedae) with Metarhizium anisopliae based microbial bio-control agents using locally affordable traps". Journal of Biological Control, 30(2), 68-77, 2016, DOI: $10.18641 / \mathrm{jbc} / 30 / 2 / 96699$.

[13] S.M.M. Abdou, K.M. Abd El-Latif, R.M.F. Farrag, K.M.R. Yousef, "Response of sunflower yield and water relations to sowing dates and irrigation scheduling under middle Egypt condition". Advances in Applied Science Research, 2(3), 141-150, 2011.

[14] H. Schmutterer, "Pests of Crops in Northeast and Central Africa: with Particular Reference to the Sudan”. Gustav Fisca Verlag, Stutgart. Portland USA. 296 pp, 1969.

[15] J.P. Grunshaw, (1992). Field studies on the biology and economic importance of Pachnoda interrupta (Coleoptera: Scarabaeidae) in Mali West Africa. Bull. Ent. Res., 82, 19-27, 1992.

[16] N.D. Jago, "Population monitoring and crop loss assessment in integrated pest management of panicle pests of sorghum and pearl millet". In: Nwanze, K.F. and Youm, O. (eds). Proceedings of an International Consultative Workshop on Panicle Insect Pests of Sorghum and Pearl Millet, 4-7 October, 1993, pp. 103- 
113. ICRISAT Sahelian Centre, Niamey, Niger. Andhra Pradesh, India: ICRISAT, (cited by Wolde-Hawariat, Y., 2008 below), 1993.

[17] B.M. Sastawa, N.E.S. Lale, "Efficacy of host plant resistance, sowing date modification and intercropping as methods for the control of Pachnoda interrupta (Olivier) in pearl millet in the Nigerian Sudan savanna". J. Arid Environ., 46, 249-262, 2000.

[18] E.M.S. Osman, "Survey, Morphometric Differences and Level of Infestation of Pachnoda interrupta (Oliver) (Coleoptera: Scarabaeidae) in Gedarif and Khartoum States". M.Sc. Thesis, University of Khartoum, Sudan, 2018.

[19] E.A. Tag Elsir, A.B. Sara, Y.M. Mohamed, "First record of the sorghum chafer, Pachnoda interrupta Olivier, (Coleoptera: Cetoniidae) outbreak on sorghum, pearl millet and sunflower in Sudan". Agricultural Research Corporation, Gezira Research Station, Wad Madani, Sudan, 2013. 